\title{
Conversations with the Chora: A Menippean Dialogue Between Toril Moi and The Night Cow
}

\author{
Kathryn Alexander
}

\section{Conversations avec la Chora: \\ Un dialogue menippean de Toril Moi et la vache nocturne}

Ce dialogue a été créé après la lecture de Sexual / Textual Politics de Toril Moi et de 'Night Cows' de Jovette Marchessault tiréde Lesbian Triptych. La 'vache nocturne' de Marchessault semble épouser les caractéristiques de la 'chora' que Moi dépeint dans son débat sur la 'Révolution du langage poétique' de Julia Kristeva.Moiamorcealorsle dialogue avec la 'Vache nocturne' et découvre qu' elle comprend le langage des 'vaches' et souhaite devenir une 'critique de vache'.

The creation of this dialogue was brought on by my reading of Toril Moi's Sexual / Textual Politics and Jovette Marchessault's Lesbian Triptych. In particular, I was captured by a numinous section of Lesbian Triptych called 'Night Cows.' Marchessault's Night Cow seems to embody the characteristics of the chora, which Moi delineates in her discussion of Julia Kristeva's Revolution of Poetic Language. Moi states that the chora is untheorizable, and describes it as 'a pulsional pressure on symbolic language and experienced as contradiction, meaninglessness, disruption, silence and absence in the symbolic language.'

Tipped off by an anonymous caller, and in search of shifting subject positions, Toril Moi, a feminist literary critic, has been led to a field on the periphery of the city. Her exhaustive investigation has finally uncovered a being who embodies the characteristics of the untheorizable chora. This Beingappears by day to be an ordinary cow. However, Moi's source insists that at night she may be witness to a startling transformation when her bovine subject turns into a Night Cow. She has brought a calf costume in hopes of getting close to the superlative cow, so that she can observe the shift of subject position. 
Toril Moi: All these cows look alike. I cannot distinguish any of these day cows from each other. They are all eating and slobbering, feeding their young, and swelling with milk. I have been told to look for the cow with the most submissive and tranquil nature, a most cow-like cow with broad haunches, abundant mammary secretions, deep chest and the sweetest liquid cow-like eyes, a cow as creamy brown as any Bossie of my childhood imaginations.

By re-engaging her long forgotten childlike imagination, Moi locates the most cow-like cow in the herd. She knows she has found the right cow when she spots the prerequisite calf feeding contentedly from the swollen udders.

Moi: How disturbing, I feel envy for that calf, my whole body aches to revisit that lacto-paradise.

She settles in the grass along the fence that separates the cows from the open road.

Moi: Such meaty, earthy creatures. In this muddy, grassy meadow it feels as if time and space have stopped. The sun, dirt, cow breath and urine fill my nostrils. The cows swim before my eyes, undifferentiated and random. I cannot bear it, my tongue is beginning to swell and lie still. I feel so content, so stupefied and sleepy, yet I feel so isolate. I can't hear my cow talk.

Moi decides that she must cross over the fence that separates her from the cows, furthermore that she must don the calf costume in order to get nearer to the mother and calf. When she draws on the costume, the hide clings as if it were her original flesh. She discovers what it means to walk on all fours, to lose hervoice and be silent, to lose the faculty of her opposable thumbs and digits of manipulation.

Moi: It's such hard work, walking on all fours, and I find this position disturbing and so exposed. Sweat is trickling through my hideand my vision has become so limited. I've lost my hindsight, bilateral and peripheral vision. All I can see is mud, grass, the blur of my body, and the other cows and calves. I keep contact with my great big mother cow by smell and touch. Her deep brown silence speaks to me in a language that is rounded out by snorts, sighs, and murmurs which are always out of reach, just beyond my understanding. 
Overcome by her experience as an animal body, Toril Moi falls asleep. When she awakes, she finds herself at the centre of a ring of watchful, protective, curious cows. Hermaternal Day/Night cow stands patientlyby, and speaks.

Day Cow: How can she learn my history? Does she know where she came from? Her origins? Where does she go after she generates theories? Can she follow them through the world, like calves? What will be left for her to be?

Moi: Now it is the evening hour, when the song of night floats up from the town. All the cows have drifted quietly to the stream that borders the meadow and are beginning to bathe. The chaotic moos, groans and snuffles of the day steadily mount into a musical phrase just beyond articulation so that I can only feel it as a pressure resonating on the inside of my chest cavity and ears. I am overcome by lassitude, and a desire to shed my skin in the river. In relief, my clumsy clambering body sloughs off its confining hide. An ineffable lightness floods my body. Before my eyes I have become a shimmering net of pulsations which shift to amorphous shapes, appearing cow-like, then womanlike, then cow-like again. My woman-calf body lies curled safely encircled by the feet of my watchful bovine aunties, who have given up their freedom in the stars tonight to guard my little meat body. So I leave and travel with the choir of Night Cows, to streak across the sky, a streaming river of coloured milky light. Amazed and enraptured, I swoop, soar and swim in the canals of milkblooming with water lilies. I feel myself moving in the core of my mother's belly, and yet, I see that we ourselves, as well as our mothers, are the sources of this abundance that spurts, gushes, drenches every pore, every thought. The living world throbs in the white galaxies of the mammalian brain, my mother's undulating cortex. My desire for her is umbilical.

As we fly, feed and sing, transported in the cacophony of our ecstatic flight, I distinguish my mother's voice and my mother's mother's voice, and her mother's voice. Suddenly I understand, we are all daughters of mothers, linked to the first kine of our mind.Our union has nothing to do with form or history. Our meaning is not limited to a definable moment or boundary or genotype.

Struggling to regain control of hercritical-woman-body, Moiattempts todifferentiate her various voices. 
Moi the critic: Iam paralyzed by the loss of my political languagebody. How will I beable to describe, analyze, or speak of this? How translate cow time into phonic increments? How speak in a language that issues from my multiple bellies, in a body where I cannot locate my mind? I can no longer distinguish myself from that calf over there, breathing in the gorgeous love milk of her mother, nor that one butting the belly of plenitude with joy, with such abandon. I feel my own head ache with her pleasure, my belly swell with her nourishment. Where has my distance gone? This is not good for the critic in me.

Moi the night calf: When I attempt to speak to my mother, the Night Cow, I hear a multiplicity of songs. She is a cacophonic wonder of rhythm, sound, music and murmured stories. In between her soft mooing I hear water and the forest, swamp, raindrops, grass blades even the interstices between the particles of dust.Quite marvelous my mother's speaking voice, and every voice has its own astonishing story, and they each resonate from the centre of my solar plexus and from behind my eyes.

Night Cow: We are traveling so you can learn that you are not just a meat thing, nor a mind thing. You are a living strategy, and your thoughts are tied to the syncopated dance of those stars you recognise as sister cows. Don't try to seek me-you cannot find me-I am everywhere. Mostly, I am the thing you reject and desire most violently. I force you to order and breath, the blushes of your lungs are my autonomic wisdoms, the body's kinetic pulsations my binding thoughts. We are fused and your theory is no protection from me. Your theory is narrow; it shapes a politic that forgets the disemboweling knife, nor remembers the violence of stinking fear. Your theory procures the mechanized births of our meat-daughters, it spices the exquisite dining pleasure of the cannibal men. You have not faced your disgust for the sweaty bleeding animal that houses you and me. I am a cow-and so are you.

Moi: Before you I am goaded into rage, delight and terror. Into language, which I recognise as separation. A part of me refuses you, I cannot proclaim, as the poet does: 'My mother is a cow. That makes two of us.' Yet I cannot bear the separation of our bodies, the separation within my body, so I struggle with a hostile language to reconcile my 
cow-hating condition. Every time I try to order my experience I slip into forgetfulness, like the sleeping body left on the grass below. How can I, the critic, and the cow-woman-body co-exist?

Night Cow: You have a tongue and a mouth that speaks, hands and digits that write. You are forced to language just as I am forced to nourish, to recycle. Your revolution is re-ordering. Re-vision your impulse. You can recover your position and alter the cannibal symbologies that have hypnotized us. Cows have always irresistibly fallen under the power of speech. Now, shake the cow body awake! During the day you will recognize many of these fat day cows in the sleeping, reading audience. You will remember the sweet trusting eyes and our addictive tranquility.

Moi: At least in the cow body, you are benevolently tolerated and slaughtered quickly with the minimum of pain. As women, we represent the terror of Otherness, the bifurcated mirror, the deep bloody mysteries which devour the imperative of the father's cannibal language. We have no substance in that masculine medium, we are shadows, mute and amorphous. Yet, unrepresented as we are now, we are freed to create our own presence. Women are writing theirown bodies of meaning, harvesting unformulated equations of existence. The patriarchal template which governs language has accustomed us to death with every page, every breath. If we refuse resolution, if we refuse a monologic subject position, then we may survive to suggest the next phase that will arise from the interstices of the next page.

Night Cow: Become a night cow, and your sentences will become sentient. Your utterances will swell and become replete and continuous. What is the word for four stomached mammals? Ruminants. Cows are the ruminating animals, just as humans are the languaging animals. Cows are cosmic philosophers, chewing the clouds and cuds, ruminating, meditating, lactating, mindful mouthfuls. For a cow, hierarchy is an impossible fiction. It does not exist in our system, our bodies dictate our philosophy. Can we establish priorities among our four stomachs? Between the importance of our udders, our long flanks, our beautiful poet's eyes? Our bodies are poems that will not end, we undulate with endlessly deferred meanings, we move throughout the open fields of our living texts, re-reading, re-feeding 


\section{Conversations with the Chora $\cdot 29$}

memories and meanings that are never resolved. We take in the world: incorporating, digesting, disintegrating and harvesting the field. When you become a cow your sentences will be sentient.

Toril Moi awakes to find herselflying on the grass beside the Night Cow. It is morning, and her Night Cow is slowly transforming into a glossy, brown Day Cow. Toril Moi discovers that she can intercept the meanings behind the snorts, slobbers and snuffles of the day cow. There is language between the silence and the crunching mouthfuls of grass.

Day Cow: Women are cows, over-determined metaphors. Neither our multiplicity nor our wise pleasures have permeated the cultural membrane, yet we exist in the cultural body, viral, vortical and vivacious.

Moi: Then I will become a cow.

Night Cow: You are already.

Moi: Can I still remain a critic, while being a cow?

Night Cow: As ruminants, all cows are the most discriminating of critics.

Moi: Will I be understood as a ruminating cow critic?

Night Cow: Most cows in your field will understand your texts.

\section{Works Cited}

Kristeva, Julia. The Kristeva Reader. Edited by Toril Moi. Columbia University Press: New York. 1986.

Marchessault, Jovette. 'The Night Cows.' Lesbian Triptych. Trans. Yvonne M. Klein. The Women's Press: Toronto. 1985.

Moi, Toril. Sexual / Textual Politics: Feminist Literary Theory. Methuen: New York. 1985. 